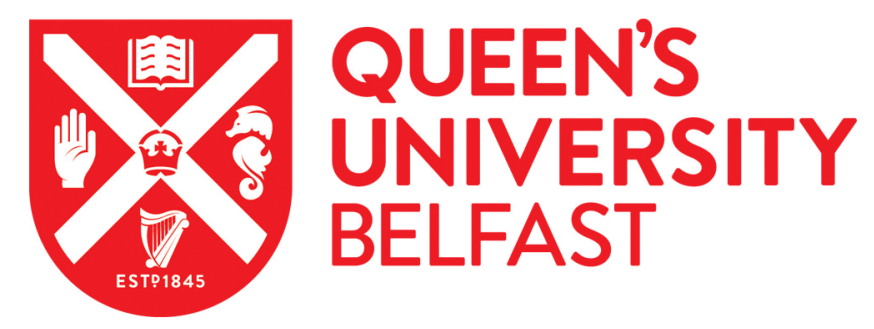

\title{
Phylogeographical analysis of two cold-tolerant plants with disjunct Lusitanian distributions does not support in situ survival during the last glaciation
}

Beatty, G. E., \& Provan, J. (2014). Phylogeographical analysis of two cold-tolerant plants with disjunct Lusitanian distributions does not support in situ survival during the last glaciation. Journal of Biogeography, 41(11), 21852193. https://doi.org/10.1111/jbi. 12371

Published in:

Journal of Biogeography

Document Version:

Peer reviewed version

Queen's University Belfast - Research Portal:

Link to publication record in Queen's University Belfast Research Portal

\begin{abstract}
Publisher rights
() 2014 John Wiley \& Sons Ltd

This is the peer reviewed version of the following article: Beatty, G. E., Provan, J. (2014), Phylogeographical analysis of two cold-tolerant plants with disjunct Lusitanian distributions does not support in situ survival during the last glaciation. Journal of Biogeography, 41:

2185-2193, which has been published in final form at http://onlinelibrary.wiley.com/doi/10.1111/jbi.12371/abstract. This article may be used for non-commercial purposes in accordance with Wiley Terms and Conditions for Self-Archiving

General rights

Copyright for the publications made accessible via the Queen's University Belfast Research Portal is retained by the author(s) and / or other copyright owners and it is a condition of accessing these publications that users recognise and abide by the legal requirements associated with these rights.
\end{abstract}

Take down policy

The Research Portal is Queen's institutional repository that provides access to Queen's research output. Every effort has been made to ensure that content in the Research Portal does not infringe any person's rights, or applicable UK laws. If you discover content in the Research Portal that you believe breaches copyright or violates any law, please contact openaccess@qub.ac.uk. 


\section{Phylogeographic analysis of two cold-tolerant plants with} disjunct Lusitanian distributions does not support in situ survival during the last glaciation

Gemma E. Beatty ${ }^{1}$ and Jim Provan ${ }^{1,2}$

${ }^{1}$ School of Biological Sciences, Queen's University Belfast, 97 Lisburn Road, Belfast BT9 7BL, Northern Ireland

${ }^{2}$ Institute for Global Food Security, Queen's University Belfast, Northern Ireland

Date of receipt:

Correspondence: Dr. Jim Provan

School of Biological Sciences

Queen's University Belfast

97 Lisburn Road

Belfast BT9 7BL

E-mail: J.Provan@qub.ac.uk

Running head: $\quad$ Phylogeography of Pinguicula grandiflora and Saxifraga spathularis

Word count: $\quad 4,385$ 


\section{$1 \quad$ ABSTRACT}

3 Aim We used a combination of modelling and genetic approaches to investigate whether

$4 \quad$ Pinguicula grandiflora and Saxifraga spathularis, two species which exhibit disjunct

5 Lusitanian distributions, may have persisted through the Last Glacial Maximum (LGM, ca.

$6 \quad 21 \mathrm{ka})$ in separate northern and southern refugia.

7

8 Location Northern and eastern Spain and southwestern Ireland

10 Methods Palaeodistribution modelling using MAXENT was used to identify putative refugial 11 areas for both species at the LGM, as well as to estimate their distributions during the Last Interglacial (LIG, ca. $120 \mathrm{ka}$ ). Phylogeographic analysis of samples from across both species' ranges was carried out using one chloroplast and three nuclear loci for each species.

15 Results The palaeodistribution models identified very limited suitable habitat for either

16 species during the LIG, followed by expansion during the LGM. A single, large refugium across northern Spain and southern France was postulated for P. grandiflora. Two suitable regions, one in Northern Spain which corresponds to the eastern part of the species' presentday distribution in Iberia, as well another on the continental shelf off the west coast of Brittany, south of the limit of the British-Irish ice sheet, were identified for S. spathularis.

21 Phylogeographic analyses indicated extremely reduced levels of genetic diversity in Irish populations of $P$. grandiflora relative to those in mainland Europe, but comparable levels of diversity between Irish and mainland European populations of S. spathularis, including the occurrence of private hapotypes in both regions. 
26 Main conclusions Modelling and phylogeographic analyses indicate that $P$. grandiflora

27 persisted through the LGM in a southern refugium, and achieved its current Irish distribution

28 via northward dispersal after the retreat of the ice sheets. Although the results for $S$.

29 spathularis are more equivocal, a similar recolonization scenario also seems the most likely

30 explanation for the species' current distribution.

31

32 Keywords

33 Large-flowered butterwort, Last Glacial Maximum, Lusitanian flora,

34 palaeodistribution modelling, Pinguicula grandiflora, phylogeography, refugia,

35 Saxifraga spathularis, St. Patrick’s cabbage. 
The present day distributions of many Northern Hemisphere temperate species are largely the result of the climatic fluctuations that occurred throughout the Pleistocene (1.8 Ma $-10 \mathrm{ka}$; Webb \& Bartlein, 1992; Hewitt, 2003). During the extended glacial periods, many of these species persisted in climatically suitable refugia, usually south of the ice sheets, and recolonized formerly glaciated areas following the retreat of the ice during the interglacials, achieving their current distributions by the Holocene (10 ka-present; Taberlet et al. 1998; Hewitt 1999). In recent years, however, this simple "expansion-contraction" paradigm of species' persistence throughout the glacial periods has been challenged by palynological and phylogeographic evidence, which suggests that some species might have persisted in 2008; Provan and Bennett 2008).

The distribution of the so-called "Lusitanian" flora, a group of about a dozen plant species that are found only in southern and western Ireland and northern Iberia, has long puzzled biogeographers. Some botanists proposed that this disjunct distribution was the result of persistence in separate northern and southern refugia during the ice ages, whilst others insisted that not even the hardiest of cold-tolerant plants could survive through the Last Glacial Maximum (LGM; ca. 21 ka) in situ (Forbes 1846; Reid 1913; Praeger 1939; Webb 1983). Recently, the first phylogeographic study on a Lusitanian plant species, the heath Daboecia cantabrica, suggested that the species had been confined to southern refugia during the LGM, and had achieved its Irish distribution following the deglaciation (Beatty and Provan 2013). D. cantabrica has minute seeds conducive to dispersal, and it may be that its glacial history is not typical of the Lusitanian flora as a whole, particularly for cold-tolerant

60 species which may have been more likely to survive in northern refugia. 
61 In the present study, we have used a combination of palaeodistribution modelling and 62 phylogeographic analysis to determine whether two of the more cold-tolerant Lusitanian 63 plant species, Pinguicula grandiflora Lam. (Large-flowered butterwort) and Saxifraga 64 spathularis Brot. (St. Patrick's cabbage), might have survived in northern refugia during the 65 LGM. S. spathularis has a typical Lusitanian distribution, being found only in northwestern 66 Spain and southwest Ireland, whilst $P$. grandiflora has a wider distribution in Spain, being 67 found across the north of the country and into the Pyrenees, as well as sporadically in the 68 French and Italian alps, and in southwest Ireland (Figures 1a and 1b). If either species had 69 persisted in northern refugia, Irish populations would exhibit comparable genetic diversity to 70 those from Spain whilst harbouring unique genotypes, the two key phylogeographic 71 signatures of long-term persistence (Provan and Bennett 2008). 
MATERIALS AND METHODS

73

\section{Sampling and DNA extraction}

Samples were obtained for both species from across their distribution ranges either through

collection in the field or from herbarium collections (See Appendices S1a and S1b for details). In total, between 149 and 160 samples of Pinguicula grandiflora from 38 locations, and between 161 and 176 samples of Saxifraga spathularis from 41 locations were analysed.

Differences in sample numbers were due to lack of amplification in several individuals at one or more loci. DNA was extracted from field-collected material using a modified CTAB protocol (Doyle \& Doyle 1987) and from herbarium samples using the Qiagen DNeasy kit.

82

\section{Palaeodistribution modelling}

Palaeodistribution modelling was carried out to determine suitable climate envelopes for both species during the last interglacial (LIG, ca. $120 \mathrm{ka}$ ) and at the last glacial maximum (LGM, ca. $21 \mathrm{ka}$ ) using the maximum entropy approach implemented in the MAXENT software package (V3.3.3; Phillips et al. 2006). Species occurrence data between 1950 and 2000 (269 and 385 occurrences for P. grandiflora and $S$. spathularis respectively) were downloaded from the Global Biodiversity Information Facility data portal (www.gbif.org). Current-day climatic data (1950-2000; Hijmans et al. 2005) at 2.5 minute resolution were clipped to the approximate distribution area of the species (i.e. Western Europe $13^{\circ} \mathrm{W}$ to $10^{\circ} \mathrm{E}$, and $35^{\circ} \mathrm{N}$ to $60^{\circ} \mathrm{N}$ ) to reduce potential problems associated with extrapolation. Models were generated using cross-validation of ten replicate runs under the default MAXENT parameters. Model performance was assessed based on the area under the receiver operating characteristic curve (AUC). Models were projected onto reconstructed climate data for the LGM (two models: 
97 LGM models were averaged to give a single consensus model. To identify areas where the model has extrapolated beyond current climatic conditions, which could lead to unreliable predictions, we carried out a multivariate environmental similarity surfaces (MESS) analysis

100 (Elith et al. 2010) in MAXENT.

101

\section{DNA sequencing}

Sequence data were obtained from one chloroplast locus (the $\operatorname{trn} \mathrm{L}-\operatorname{trn} \mathrm{F}$ intergenic spacer for

P. grandiflora and the trnS-trnG intergenic spacer for S. spathularis) and three anonymous single-copy nuclear loci for each species (details and primer sequences are given in Appendix S2). Primers to amplify anonymous single-copy nuclear DNA loci were developed using the ISSR-cloning method described in Beatty et al. (2010). For herbarium samples from which the complete chloroplast product could not be amplified in a single PCR, the region was amplified as two or three overlapping fragments using internal primers (Appendix S3). PCR was carried out on a MWG Primus thermal cycler (Ebersberg, Germany) using the following

111 parameters: initial denaturation at $94{ }^{\circ} \mathrm{C}$ for 3 min followed by 45 cycles of denaturation at 94

$112{ }^{\circ} \mathrm{C}$ for $30 \mathrm{~s}$, annealing at $58^{\circ} \mathrm{C}\left(52{ }^{\circ} \mathrm{C}\right.$ for $S$. spathularis trnS-G intergenic spacer $)$ for $30 \mathrm{~s}$, 113 extension at $72{ }^{\circ} \mathrm{C}$ for $1 \mathrm{~min}$ and a final extension at $72{ }^{\circ} \mathrm{C}$ for $5 \mathrm{~min}$. PCR was carried out in

114 a total volume of $20 \mu \mathrm{l}$ containing $200 \mathrm{ng}$ genomic DNA, 10 pmol of each primer, 1x PCR

115 reaction buffer, $200 \mu \mathrm{M}$ each dNTP, $2.5 \mathrm{mM} \mathrm{MgCl}_{2}$ and $0.5 \mathrm{U}$ GoTaq Flexi DNA

116 polymerase (Promega, Sunnyvale, CA). Five $\mu$ PCR product were resolved on 1.5\% agarose

117 gels and visualised by ethidium bromide staining, and the remaining $15 \mu \mathrm{l}$ were EXO-SAP

118 purified and sequenced in both directions using the BigDye sequencing kit (V3.1; Applied

119 Biosystems) and run on an AB 3730XL DNA analyser (Life Technologies; Carlsbad, 120 California, USA). 
123 DNA sequences were aligned in BIOEDIT (V7.0.9.0; Hall, 1999). For the single-copy

124 nuclear loci, haplotypes were resolved for individuals exhibiting two or more heterozygous

125 positions using the PHASE program (V2.1; Stephens \& Donnelly 2003) implemented in the

126 DnaSP software package (V5.10; Librado \& Rozas 2009). Pinguicula grandiflora is

127 tetraploid (Heslop-Harrison 2004), but to avoid difficulties with estimation of allele dosage,

128 all heterozygotes were scored as 50:50 i.e. similar to treatment of diploid loci. Given the

129 extremely low levels of heterozygosity observed in Irish populations relative to continental

130 European populations, this should not unduly affect our conclusions regarding the glacial

131 history of the species. Potential recombination was assessed using the Hudson \& Kaplan

132 (1985) test in DnaSP. Median-joining networks for all loci were constructed using the

133 NETWORK software package (V4.5.1.6; www.fluxus-engineering.com). Any reticulations in

134 the networks were broken following the rules described in Pfenninger \& Posada (2002).

135 Levels of haplotype diversity $(H)$ and nucleotide diversity $(\pi)$ were calculated using DnaSP.

136 To account for differences in sample sizes, particularly in the case of S. spathularis, levels of

137 haplotype richness $\left(R_{h}\right)$ were calculated using HAPLOTYPE ANALYSIS (V1.05; Eliades \&

138 Eliades 2009).

139 To assess potential geographical structuring of genetic variation in continental European

140 populations associated with persistence in multiple glacial refugia, we performed a spatial

141 analysis of molecular variance (SAMOVA) using the SAMOVA software package (V1.0;

142 Doupanloup et al. 2002) for each of the eight data sets. The program uses a simulated

143 annealing approach based on genetic and geographical data to identify groups of related

144 populations. The program was run for 10,000 iterations for $K=2$ to 10 groups from 200

145 initial conditions, and the most likely structure was identified using the maximum value of

$146 \Phi_{\mathrm{CT}}$ that did not include any groups of a single population. 
RESULTS

\section{Palaeodistribution modelling}

150 For all models, AUC values were high $(P$. grandiflora mean $\mathrm{AUC}=0.944 \mathrm{SE}=0.008 ; S$.

151 spathularis mean AUC $=0.973 \mathrm{SE}=0.005$ ). Palaeodistribution modelling of species

152 distributions suggested far more restricted ranges during the LIG compared to current

153 distributions, particularly for S. spathularis (Figures 1c and 1d). The models suggested that

154 both species had larger potential distribution ranges during the LGM. For P. grandiflora,

155 extensive regions of suitable habitat coincided largely with the species' current distribution in

156 continental Europe, with additional areas in southern France where the species is currently

157 absent (Figure 1e). Two main areas of suitable habitat during the LGM were identified for $S$.

158 spathularis, one in Northern Spain which corresponds to the eastern part of the species'

159 present-day distribution in Iberia, as well another on the continental shelf off the west coast

160 of Brittany, south of the limit of the British-Irish ice sheet (Figure 1f).

\section{Phylogeographic analysis}

163 Between three (trnL-F) and twelve (Pg-C01 and Pg-F10) haplotypes were found in the four

164 loci analysed in P. grandiflora (Table 1 and Figure 2). Populations from continental Europe

165 harboured far higher levels of diversity than those from Ireland, with total of 37 haplotypes

166 across the four loci, including 31 private haplotypes, compared to six haplotypes (one

167 private) in Irish populations. The frequency of private alleles ranged from 0.09 (Pg-C02) to

1680.46 (trnL-F) in continental Europe, whilst the sole private allele in Irish populations, at locus

169 Pg-F10, was only found at a frequency of 0.01. Levels of haplotype richness $\left(R_{h}\right)$, haplotype

170 diversity $(H)$, and nucleotide diversity $(\pi)$ ranged from $2.000(\operatorname{trn} \mathrm{L}-\mathrm{F})$ to $9.087(\mathrm{pg}-\mathrm{F} 10)$,

171 from 0.179 (Pg-C01) to 0.606 (trnL-F), and from 0.0007 (Pg-F10) to 0.0030 (Pg-F02) 
172 respectively in continental European populations, and from zero (trnL-F and Pg-C02) to

1730.480 (Pg-F02), from zero (trnL-F and Pg-C01) to 1.000 (Pg-F02 and Pg-F10), and from zero

174 (trnL-F and Pg-C01) to 0.0036 (Pg-F02) respectively in Irish populations.

175 Evidence for recombination was detected at all three nuclear loci analysed in $S$.

176 spathularis. Consequently, subsequent analyses were carried out using only the largest non-

177 recombining portion of each locus (see Appendix S3 for details). The chloroplast trnS-G

178 intergenic spacer region exhibited eleven haplotypes in Spain $\left(R_{h}=10.000, H=0.872, \pi=\right.$

179 0.0020), but only a single haplotype in Ireland (Table 1 and Figure 3). For three nuclear loci,

180 values for $R_{h}, H$ and $\pi$ ranged from 3.000 (Ss-G04) to 5.000 (Ss-C02), from 0.238 (Ss-G04)

181 to 0.557 (Ss-G07), and from 0.0026 (Ss-G04) to 0.0076 (Ss-C02) respectively in Spain, and

182 from 1.000 (Ss-G04) to 4.491 (Ss-C02), from 0.162 (Ss-G04) to 0.581 (Ss-C02), and 0.0017

183 (Ss-G04) to 0.0084 (Ss-C02) respectively in Ireland. All four loci exhibited private

184 haplotypes in Spain, whilst two of the four (Ss-C02 and Ss-G07) had private haplotypes in 185 three of the Irish populations studied.

186 For both species, none of the SAMOVA analyses (four loci for each species) indicated 187 any obvious geographical structuring of genetic variation (data not shown). 


\section{DISCUSSION}

190 Phylogeographic studies are increasingly being used in conjunction with palaeodistribution

191 modeling to provide insights into the response of species to the glacial periods of the late

192 Pleistocene (for reviews see Chan et al. 2011; Alvaredo-Serrano \& Knowles 2014). It is

193 important, however, to appreciate the potential pitfalls and problems of such modeling

194 approaches, particularly for species with restricted and/or limited distributions, as is the case

195 for the Lusitanian flora. The main drawback with ecological niche models based on

196 correlative approaches is that these approaches assume species / environment equilibrium, a

197 condition which is frequently violated when examining range-shifts such as those associated

198 with the glaciations (Menke et al. 2009; Elith et al. 2010). The incorporation of multivariate

199 environmental similarity surface (MESS) methods (Elith et al. 2010) into the most recent

200 versions of the MAXENT modeling software package (V3.3.2 onwards) allows identification

201 of areas in the model where extrapolation is greatest, and consequently where prediction may

202 be less reliable e.g. areas that lie under the ice sheets at the LGM (Figure S3, Additional

203 Supporting Material). When applied to the LIG and LGM models for both of our study

204 species, the only modeled area that was associated with strongly negative (i.e. less than -10)

205 MESS values, and consequently may reflect unreliable prediction, was the northeastern part

206 of the modeled LGM range for P. grandiflora in eastern Aquitaine and the Midi-Pyrénées

207 regions of France. The apparently larger distributions for both species at the LGM relative to

208 the LIG may reflect the fact that they are cold-tolerant to some degree (Webb 1983), and

209 many cold-tolerant species have been suggested to have larger distributions during glacial

210 periods (reviewed in Bennett \& Provan 2008; Stewart et al. 2010). Nevertheless, although

211 the observed patterns of genetic variation in P. grandiflora are consistent with the occurrence

212 of a single large refugium (see below), caution should be exercised when trying to make 
213 inferences on past ranges for species with restricted distributions (Elith et al. 2010).

214 Although all models had high AUC values, which generally indicates good predictive power,

215 these values tend to be inflated for species which occupy a limited part of the area analyzed,

216 as typified by species that exhibit disjunct distributions where large areas are unoccupied.

218 Pinguicula grandiflora - the classic southern refugium paradigm

219 Both the palaeodistribution modelling and the phylogeographic evidence indicate that $P$. grandiflora persisted throughout the LGM in a southern refugium and recolonized Ireland following the retreat of the ice sheets. Unlike Daboecia cantabrica, the only other plant with a Lusitanian distribution on which phylogeographic analysis has been carried out (Beatty \& Provan, 2013), and which survived the LGM in two southern refugia, the lack of geographical structuring of genetic variation in continental European populations of $P$. grandiflora suggests the occurrence of a single refugium. This is consistent with the large, mostly continuous area of suitable habitat at the LGM indicated by the palaeodistribution modelling. The extremely low levels of genetic diversity observed in Irish populations, coupled with the occurrence of only a single, low frequency private haplotype, are indicative of the founder effects associated with postglacial recolonization (Hewitt 1999; Provan \& Bennett 2008). This is in contrast to Webb (1983), who could conceive no mechanism whereby P. grandiflora could have reached Ireland from the Pyrenees, and concluded that the species must have persisted in situ since the interglacial. Such persistence seems unlikely, since although hibernacula can withstand low temperatures, rosettes are extremely susceptible to frost (Heslop-Harrison 1962; Grace 1987). Seeds of $P$. grandiflora are minute and dust-like (as are those of D. cantabrica), a feature which could facilitate long-distance

236 dispersal following the retreat of the ice after the LGM. 


\section{Saxifraga spathularis - evidence for persistence in a northern refugium?}

239 Whilst $P$. grandiflora exhibits the classic "southern richness vs. northern purity" pattern of 240 genetic diversity consistent with survival in southern refugia (Hewitt 1999), the distribution

241 of genetic diversity in S. spathularis initially appears incompatible with such a scenario.

242 Levels of haplotype diversity in Irish populations are comparable to those found in Spain for

243 the three nuclear loci studied, and private haplotypes are present in Ireland at two of these

244 loci, although after rarefaction to account for differences in sample size, levels are lower for

245 all three loci in Ireland. This is in contrast, however, to the data from the chloroplast trnS-G

246 intergenic spacer, which suggest an extreme bottleneck in Irish populations, effectively ruling

247 out the possibility that Iberian populations might have originated in a northern refugium. The

248 discrepancy between the chloroplast and nuclear markers is most likely due to the smaller

249 effective population size of the haploid, uniparentally inherited chloroplast genome, which

250 will be more susceptible to effects of genetic drift during the population fluctuations

251 associated with climatic changes during the Pleistocene.

252 Despite the comparable levels of nuclear diversity and occurrence of private haplotypes, it

253 seems unlikely that S. spathularis persisted through the LGM in separate northern and

254 southern refugia, as suggested by the palaeodistribution model, since this would lead to

255 phylogenetic structuring which would be reflected geographically. The opposite is apparent

256 for locus Ss-G07, where the two private haplotypes found in Ireland, depicted in yellow and

257 white, are two of the most phylogenetically divergent haplotypes, being separated by four

258 mutations. It is possible that these represent localized recent mutations, since they are present

259 at very low frequencies. Alternatively, it might be that the lower number of plants analyzed

260 from Spain means that these haplotypes are present there, but were simply not sampled.

261 The patterns of genetic variation observed in S. spathularis are similar to those reported

262 for Meconopsis cambrica, an herbaceous species with a disjunct distribution similar to that 
exhibited by the Lusitanian flora, being found in Northern Spain and the Massif Central, as well as in north Devon, Somerset, Wales and Ireland (Valtueña et al. 2012). Populations of

M. cambrica from Wales shared a single chloroplast haplotype with samples from continental European populations, including private AFLP alleles. It was suggested that these populations might have originated from a separate northern refugium, but not as far north as mainland Britain. Unlike in $M$. cambrica, however, S. spathularis populations are not separated into "northern" and "southern" groups, and Irish populations most likely shared a refugial area with present-day Spanish populations. The lack of correspondence with the palaeodistribution model, which did suggest the potential existence of separate northern and southern refugial areas, is probably a consequence of the aforementioned problems associated with extrapolating ranges of species with restricted distributions, as is the case with $S$. spathularis (Elith et al. 2010). This could also explain the extremely low levels of predicted suitable habitat during the LIG.

An alternative explanation for the occurrence of private haplotypes in Ireland could be introgression from the congeneric $S$. hirsuta. Both species occur sympatrically in Cos. Cork and Kerry, where they hybridize to form $S$. x polita (Webb, 1951). Although S. hirsuta is much less common than S. spathularis, introgression of species-specific SNP alleles from the former into the latter has been observed, even in populations of $S$. spathularis from Co. Galway where S. hirsuta is now absent (G.E. Beatty \& J. Provan, unpublished results). Such introgression is consistent with the high levels of recombination detected at all three nuclear loci, but would not affect the chloroplast genome. Unfortunately, though, it was not possible to amplify the two orthologous loci of Ss-C02 and Ss-G07 in S. hirsuta to determine whether the alleles had been introgressed into S. spathularis from its congener. 


\section{CONCLUSIONS}

288

289 The findings of the present study, together with the only previously published

290 phylogeographic study on a member of the Lusitanian flora, Daboecia cantabrica (Beatty \&

291 Provan, 2013), suggest that the original theory of persistence in separate northern and

292 southern refugia cannot explain these species' puzzling distribution. Both Pinguicula

293 grandiflora and Saxifraga spathularis, like D. cantabrica, are likely to have persisted through

294 the LGM in southern refugia and colonized Ireland after the retreat of the ice sheets.

295 Nevertheless, the differing refugial histories of the three species suggest that no one scenario

296 can account for the present-day distribution of the Lusitanian flora, and that several southern

297 refugia facilitated these species' survival during the LGM. 
300 We are extremely grateful to Robert Beatty for assistance with field sampling. Valuable

301 herbarium specimens were provided by Colin Kelleher and Noeleen Smyth (National Botanic

302 Gardens of Ireland, Glasnevin), Carmen Fernández-Carvajal (Universidad de Oviedo

303 Herbario), Elena de Paz Canuria (Universidad de León Herbario), Javier Hernández

304 (Universidad de Salamanca Herbario), José Garcia Sánchez and Baltasar Cabezudo Artero

305 (Universidad de Málaga Herbario), Neus Ibáñez Cotina (Herbari BC, Institut Botànic de

306 Barcelona), Salvador Talavera, Francisco Salgueiro González, María Jesús Ariza Molina and

307 Mercedes Márquez Pedrosa (Universidad de Sevilla Herbario), Javier Amigo Vazquez

308 (Universidad de Santiago de Compostela Herbario) and Laurent Gautier (Université de

309 Genève). We are grateful to Niall McKeown and Ian Montgomery for helpful discussions

310 and to two anonymous referees for comments that improved the manuscript. This research

311 was supported by Research Grant RPG-126 from the Leverhulme Trust. 


\section{REFERENCES}

314 Alvaredo-Serrano, D.F \& Knowles, L.L. (2014) Ecological niche models in phylogeographic

315 studies: applications, advances and precautions. Molecular Ecology Resources 14, 233-

316248.

317 Beatty, G.E., Philipp, M. \& Provan, J. (2010) Unidirectional hybridization at a species' range

318 boundary: implications for habitat tracking. Diversity and Distributions, 16, 1-9.

319 Beatty, G.E. \& Provan, J. (2013) Postglacial dispersal, rather than in situ glacial survival, best

320 explains the disjunct distribution of the Lusitanian plant species Daboecia cantabrica

321 (Ericaceae). Journal of Biogeography 40, 335-344.

322 Bennett, K.D. \& Provan, J. (2008) What do we mean by 'refugia'? Quaternary Science 323 Reviews, 27, 2449-2455.

324 Chan, L.M., Brown, J.L. \& Yoder, A.D. (2011) Integrating statistical genetic and geospatial 325 methods brings new power to phylogeography. Molecular Phylogenetics and Evolution $326 \quad 59,523-537$.

327 Doupanloup, I., Schneider, A. \& Excoffier, L. (2002) A simulated annealing approach to 328 define the genetic structure of populations. Molecular Ecology, 11, 2571-2581.

Doyle, J.J. \& Doyle, J.L. (1987) A rapid DNA isolation procedure for small quantities of 330 fresh leaf material. Phytochemical Bulletin, 19, 11-15.

331 Ehlers, J. \& Gibbard, P.L. (2004) Quaternary glaciations - extent and chronology. Part 1: 332 Europe. Elsevier, Amsterdam.

333 Eliades, N-G. \& Eliades, D.G. (2009) HAPLOTYPE ANALYsis: software for analysis of 334 haplotype data (available from www.uni-goettingen.de/en/134935.html)

335 Elith, J., Kearney, M. \& Phillips, S. (2010) The art of modelling range-shifting species. 336 Methods in Ecology and Evolution, 1, 330-342. 
Forbes, E. (1846) On the connexion between the distribution of the existing fauna and flora of the British Isles, and the geological changes which have affected their areas, especially during the epoch of the Northern Drift. Great Britain Geological Survey Memoir, 1, 336432.

Grace, J. (1987) Climatic tolerance and the distribution of plants. New Phytologist 106S, 113-130.

Hall, T.A. (1999) BIOEDIT: a user-friendly biological sequence alignment editor and analysis program for Windows 95/98/NT. Nucleic Acids Symposium Series, 41, 95-98.

Heslop-Harrison, Y. (1962) Winter dormancy and vegetative propagation in Irish Pinguicula grandiflora Lamk. Proceedings of the Royal Irish Academy, 62, 23-30.

Heslop-Harrison, Y. (2004) Biological flora of the British Isles No. 237: Pinguicula L. Journal of Ecology, 92, 1071-1118.

Hewitt, G.M. (1999) Post-glacial re-colonization of European biota. Biological Journal of the Linnean Society, 68, 87-112.

Hewitt, G.M. (2003) Ice ages: their impact on species distributions and evolution. Evolution on planet Earth (ed. by L.J. Rothschild and A.M Lister), pp. 339-361. Academic Press.

Hijmans, R.J., Cameron, S.E., Parra, J.L., Jones, P.G. \& Jarvis, A. (2005) Very high resolution interpolated climate surfaces for global land areas. Journal of Climatology, 25, 1965-1978.

Hudson, R.R.\& Kaplan, N. (1985) Statistical properties of the number of recombination events in the history of a sample of DNA sequences. Genetics 111, 47-164. polymorphism data. Bioinformatics, 25, 1451-1452. 
360 Pfenninger, M. \& Posada, D. (2002) Phylogeographic history of the land snail Candidula

361 unifasciata (Helicellinae, Stylommatophora): fragmentation, corridor migration and

362 secondary contact. Evolution, 56, 1776-1788.

363 Phillips, S.J., Anderson, R.P. \& Schapire, R.E. (2006) Maximum entropy modeling of species 364 geographic distributions. Ecological Modelling, 190, 231-259.

365 Praeger, R.L. (1939) The relations of the flora and fauna of Ireland to those of other 366 countries. Proceedings of the Linnean Society of London, 151, 192-213.

367 Provan, J. \& Bennett, K.D. (2008) Phylogeographic insights into cryptic glacial refugia.

368 Trends in Ecology and Evolution, 23, 564-571.

369 Reid, C. (1913) The relation of the present plant population of the British Isles to the glacial 370 period. Journal of Ecology 1, 42-46.

371 Sejrup, H.P., Hjelstuen, B.O., Dahlgren, K.I.T., Haflidason, H., Kuijpers, A., Nygard, A., 372 Praeg, D., Stoker, M.S. \& Vorren, T.O. (2005) Pleistocene glacial history of the NW 373 European continental margin. Marine and Petroleum Geology, 22, 1111-1129.

374 Stephens, M. \& Donnelly, P. (2003) A comparison of Bayesian methods for haplotype 375 reconstruction from population genotype data. American Journal of Human Genetics, 73, $376 \quad 1162-1169$.

377 Stewart, J.R., Lister, A.M., Barnes, I. \& Dalén, L. (2010) Refugia revisited: individualistic 378 responses of species in space and time. Proceedings of the Royal Society of London Series $379 \quad B, 277,661-671$.

380 Taberlet, P., Fumigalli, L., Wust-Saucy, A.-G. \& Cosson, J.-F. (1998) Comparative 381 phylogeography and postglacial colonization routes in Europe. Molecular Ecology, 7, $382 \quad 453-464$.

383 Valtueña, F.J., Preston, C.D. \& Kadereit, J.W. (2012) Phylogeography of a Tertiary relict 384 plant, Meconopsis cambric (Papaveraceae), implies the existence of northern refugia for a 
386 Webb, D.A. (1951) Hybrid plants in Ireland. Irish Naturalists' Journal, 10, 201-205.

387 Webb, D.A. (1983) The flora of Ireland in its European context. Journal of Life Sciences, 388 Royal Dublin Society, 4, 143-160.

389 Webb, T. \& Bartlein, P.J. (1992) Global changes during the last 3 million years: climatic 390 controls and biotic response. Annual Review of Ecology and Systematics, 23, 141-173. 


\section{BIOSKETCHES}

393 Gemma Beatty is a Postdoctoral Research Fellow at Queen's University Belfast. Her PhD

394 research compared how postglacial recolonization and range-edge effects have shaped the

395 genetic diversity of several northern hemisphere Monotropoideae species. She is interested

396 in using genetic approaches to study the effects of past and present climate change on the

397 distribution ranges of natural populations, and the various factors that determine these ranges.

398 Jim Provan is a Reader in Evolutionary Genetics at Queen's University Belfast. His

399 research interests focus on how genetic variation is distributed across species ranges, and on

400 the effects of past, present and future climate change on levels and patterns of intraspecific

401 diversity.

402

403 Author contributions: JP conceived the study; both authors collected and analysed the data, 404 and wrote the manuscript.

405

406 Editor: Hans-Peter Comes 
Table 1 Diversity statistics by region. $N$ - number of individuals; $h$ - number of haplotypes observed (number of private haplotypes in parentheses); Freq - frequency of private haplotypes; $R_{h}$ - Haplotype richness; $H$ - haplotype diversity; $\pi$ - nucleotide diversity.

\begin{tabular}{|c|c|c|c|c|c|c|c|c|c|c|c|c|c|c|}
\hline \multirow{2}{*}{ Species } & \multirow{2}{*}{ Locus } & \multicolumn{6}{|c|}{ Europe } & \multicolumn{6}{|c|}{ Ireland } & \multirow{2}{*}{$\begin{array}{l}\text { GenBank } \\
\text { Accessions }\end{array}$} \\
\hline & & $N$ & $h$ & Freq $_{p}$ & $R_{h}$ & $H$ & $\pi$ & $N$ & $h$ & Freq $_{p}$ & $R_{h}$ & $H$ & $\pi$ & \\
\hline \multirow{2}{*}{ P. grandiflora } & Pg-C01 & 180 & $12(11)$ & 0.09 & 8.951 & 0.179 & 0.0011 & 140 & $1(0)$ & - & - & - & - & \\
\hline & Pg-F10 & 166 & $11(9)$ & 0.10 & 9.087 & 0.190 & 0.0007 & 136 & $2(1)$ & 0.01 & 1.000 & 0.015 & 0.0001 & \\
\hline S. spathularis & $\operatorname{trnS}-\mathrm{G}$ & 39 & $11(10)$ & 0.85 & 10.000 & 0.872 & 0.0020 & 134 & $1(0)$ & - & - & - & - & \\
\hline
\end{tabular}




\section{Figure Legends}

Figure 1 Present-day distributions of (a) Pinguicula grandiflora, and (b) Saxifraga spathularis (shaded; based on Webb 1982 and the Global Biodiversity Information Facility [data.gbif.org]) in Europe. Palaeodistribution models for (c,e) P. grandiflora, and (d,f) $S$. spathularis during the Last Interglacial (ca. $120 \mathrm{ka})$ and the Last Glacial Maximum (ca. 21 ka) repectively. Darker areas in (c-f) show most suitable modelled habitat. The limits of the British-Irish ice sheet (after Sejrup et al. 2005) and Alpine and Pyrenean glaciers (after Ehlers \& Gibbard 2004) at the LGM are also indicated.

Figure 2 Haplotype distributions for (a) chloroplast trnL-F intergenic spacer, (b) nuclear Pg-C01 region, (c) nuclear Pg-F02 region, and (d) nuclear Pg-F10 region for Pinguicula grandiflora. Pie chart sizes are approximately proportional to sample size, with the smallest circles representing $N=1$ (chloroplast locus) or $N=2$ (nuclear loci) and the largest representing $N=8$ (chloroplast locus) or $N=16$ (nuclear loci). In the haplotype networks, black circles represent unique haplotypes found in a single individual, and open diamonds indicate missing (unsampled) haplotypes.

Figure 3 Haplotype distributions for (a) chloroplast trnS-G intergenic spacer, (b) nuclear Ss-C02 region, (c) nuclear Ss-G04 region, and (d) nuclear Ss-G07 region for Saxifraga spathularis. Pie chart sizes are approximately proportional to sample size, with the smallest circles representing $N=1$ (chloroplast locus) or $N=2$ (nuclear loci) and the largest representing $N=8$ (chloroplast locus) or $N=16$ (nuclear loci). In the haplotype networks, black circles represent unique haplotypes found in a single individual, and open diamonds indicate missing (unsampled) haplotypes. 


\section{SUPPORTING INFORMATION}

Additional Supporting Information may be found in the online version of this article:

Appendix S1a Samples of Pinguicula grandiflora analysed

Appendix S1b Samples of Saxifraga spathularis analysed

Appendix S2 PCR / sequencing primers used in this study.

Figure S3 Results of the multivariate environmental similarity surfaces (MESS) analysis for

(a) LIG, and (b) LGM models. Darker blue areas highlight regions with more highly negative MESS values, indicating areas where the model has extrapolated beyond current climatic conditions, which could lead to unreliable predictions. 

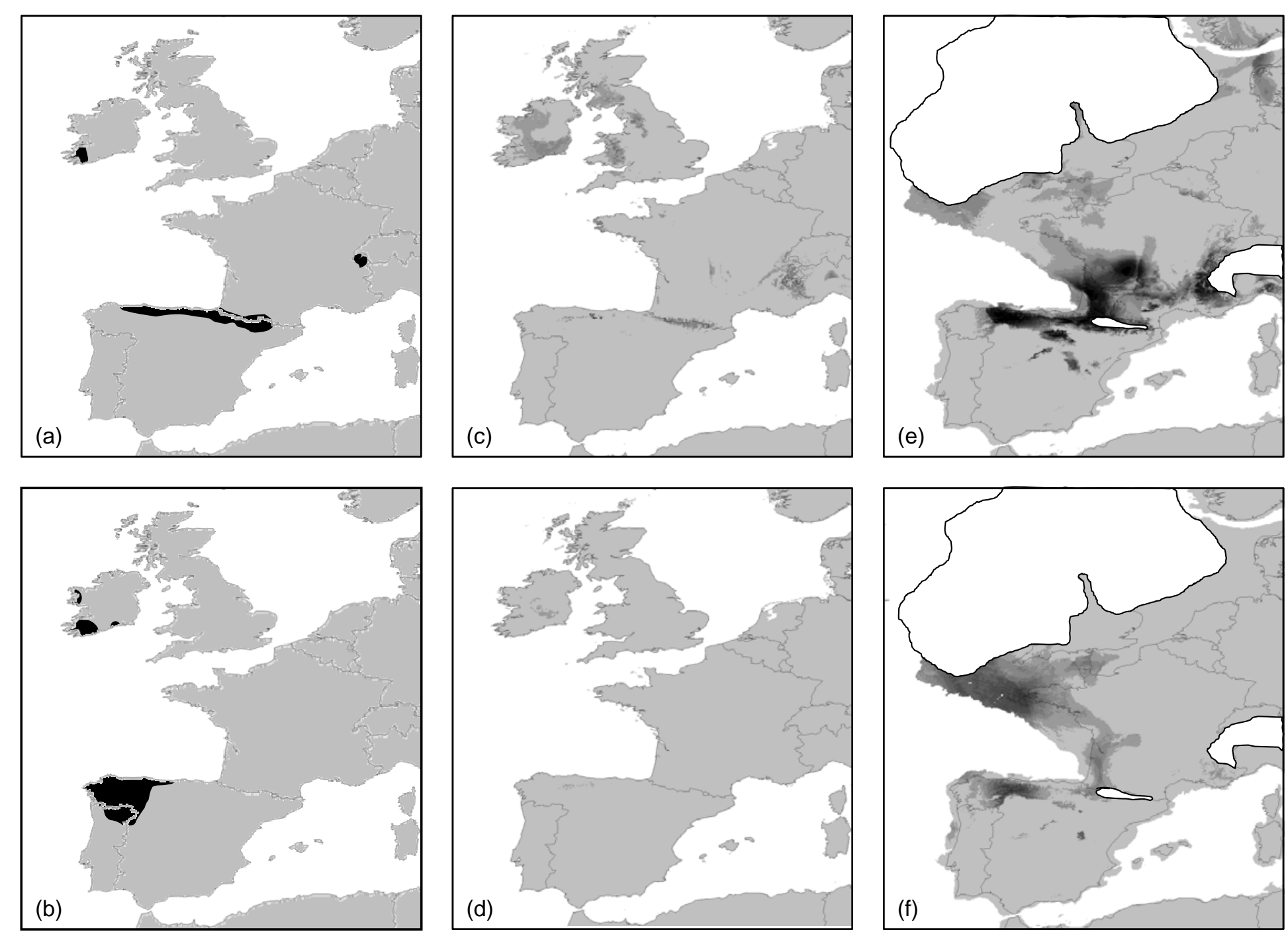

Page | 25 
(a)
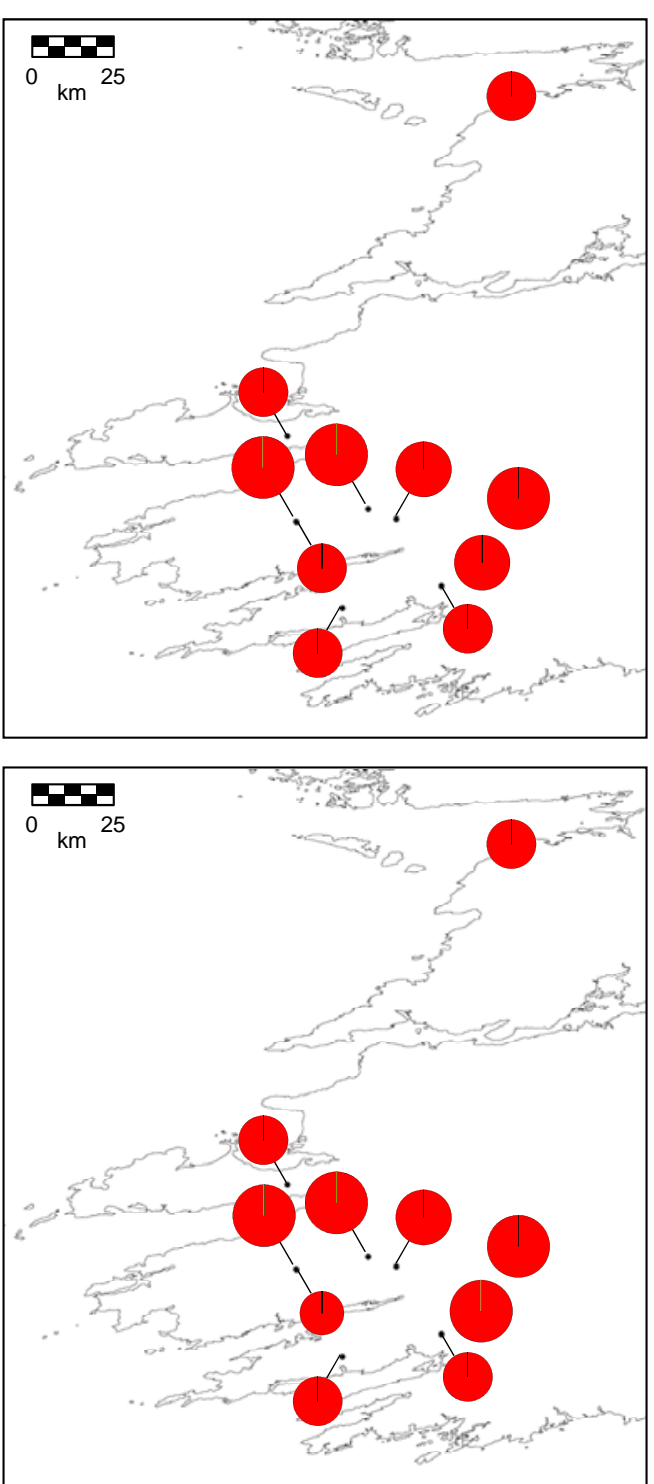
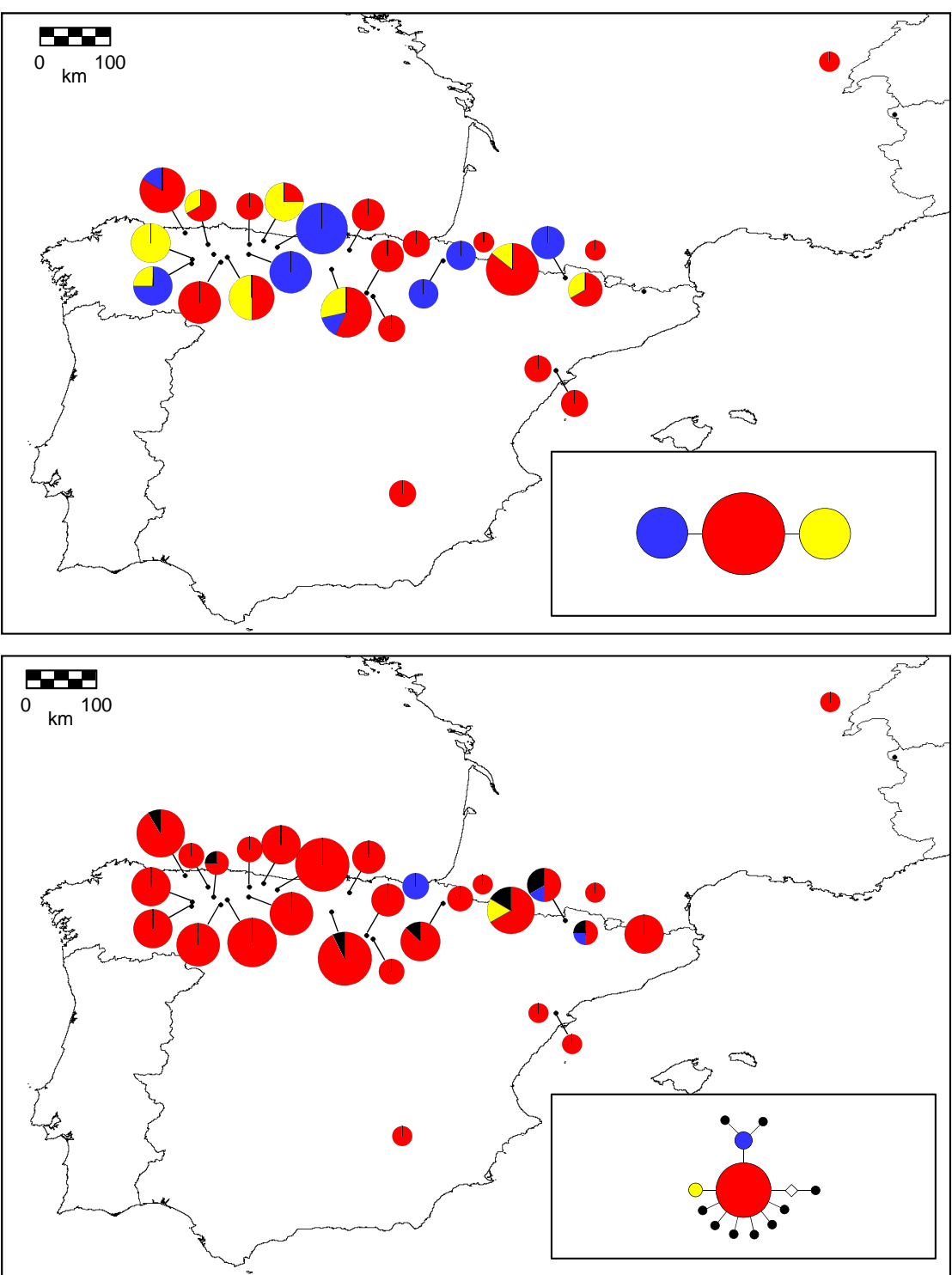

Page $\mid 26$ 
(c)
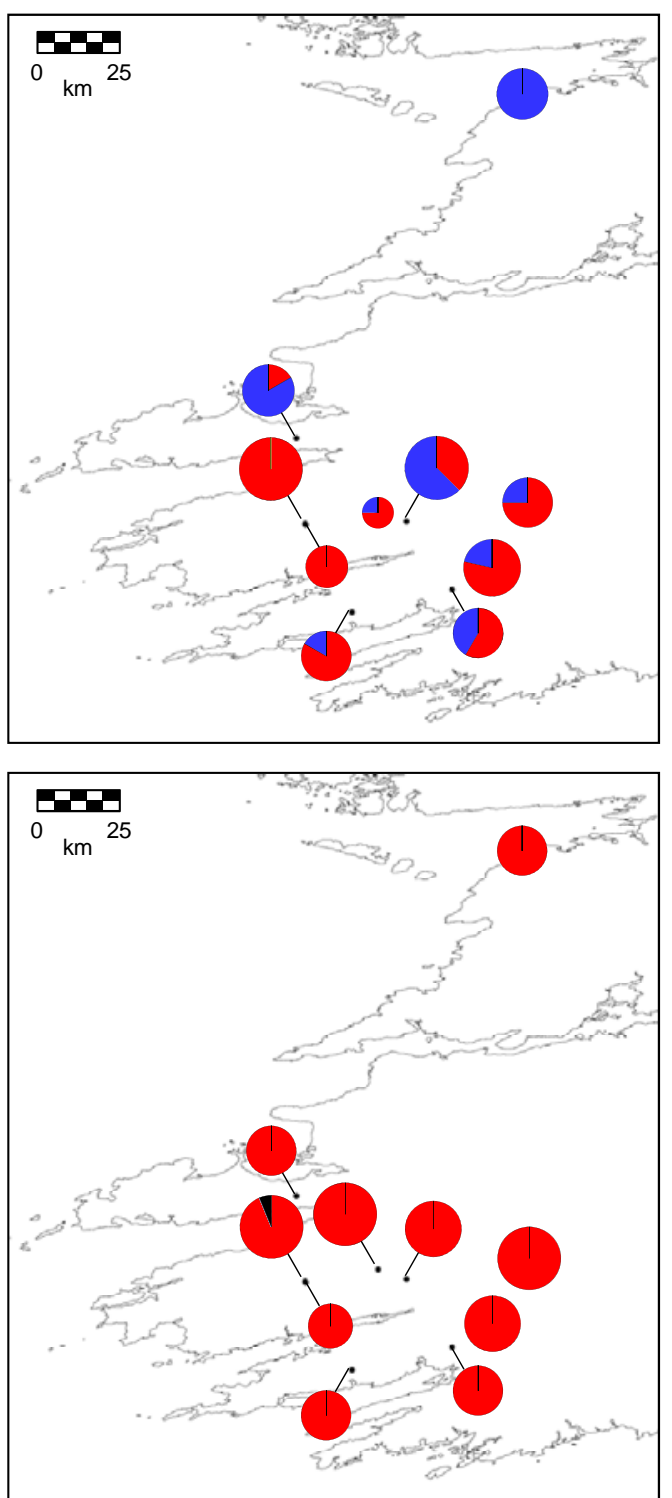
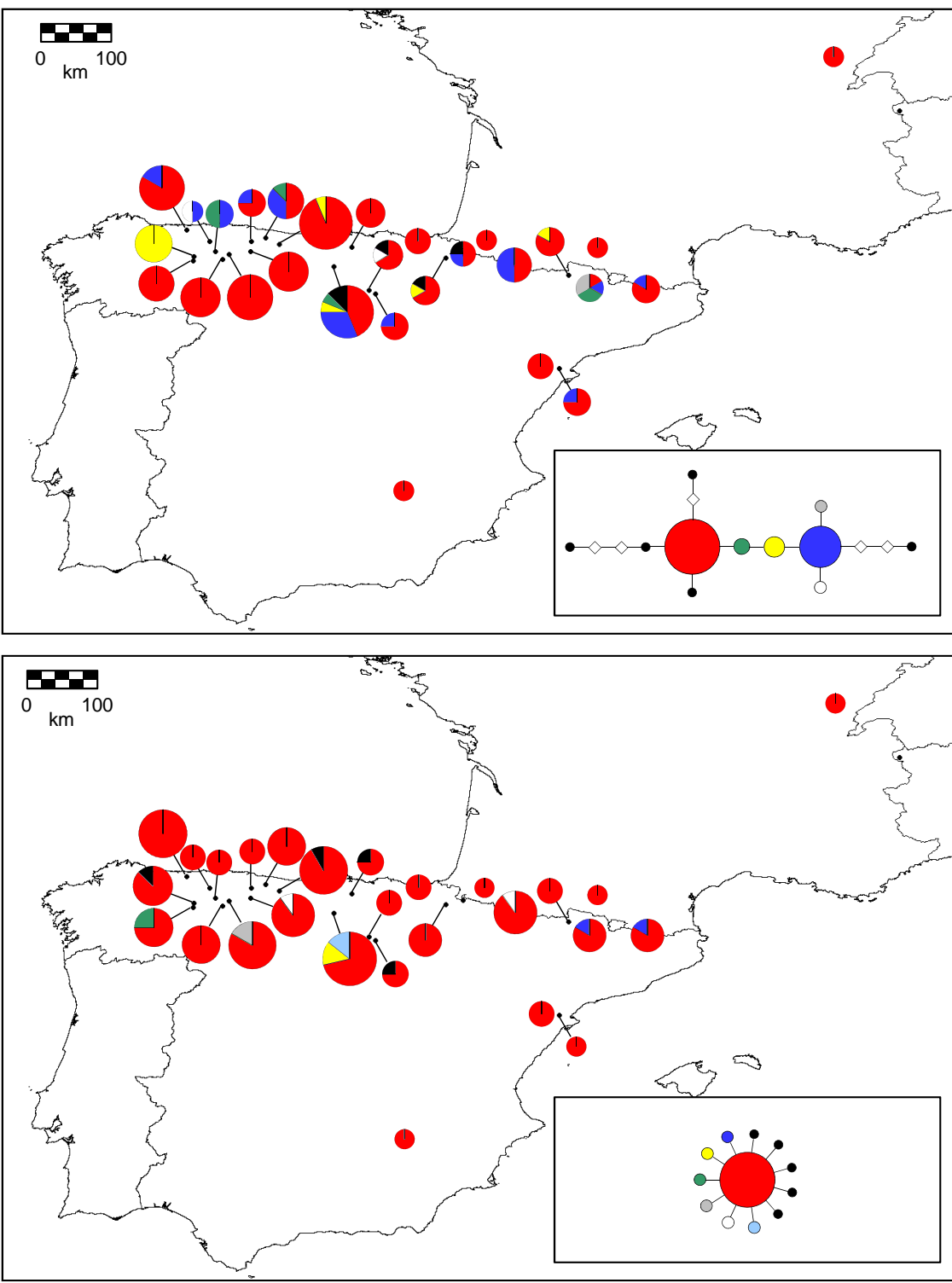

Page | 27 
(a)

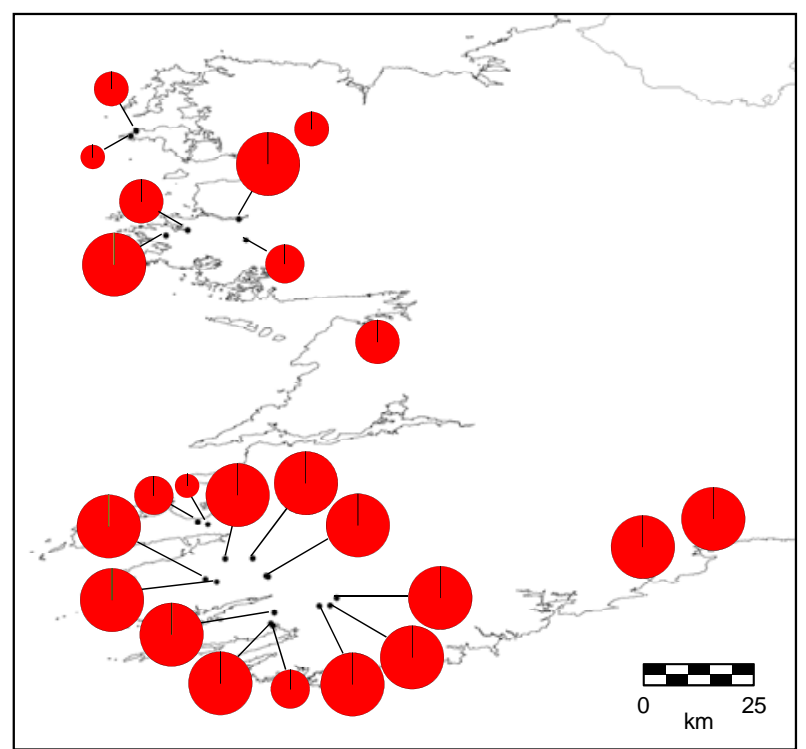

(b)

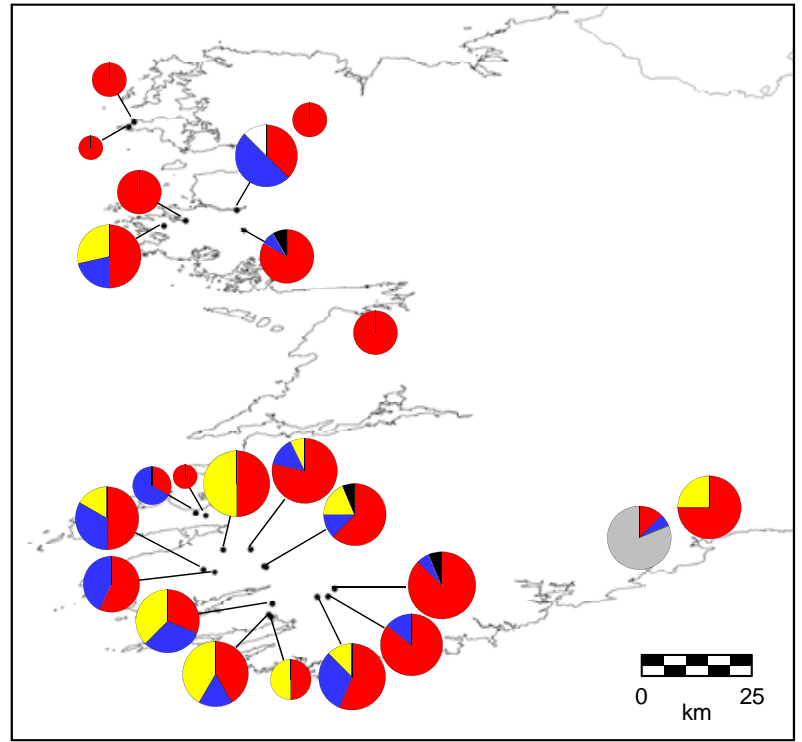

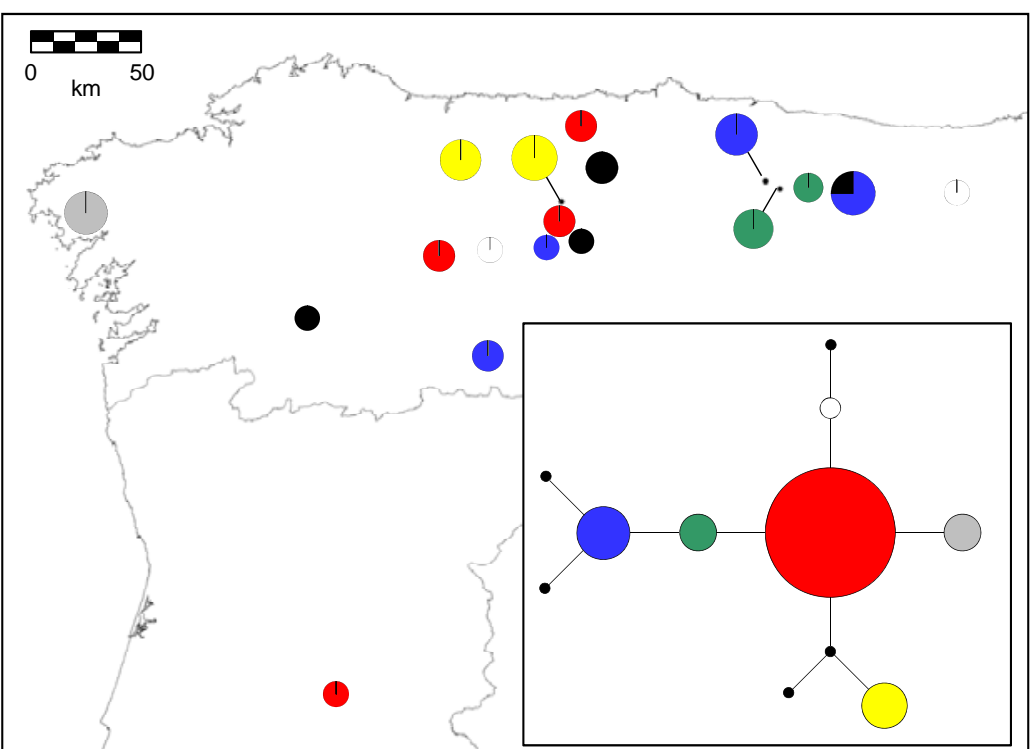

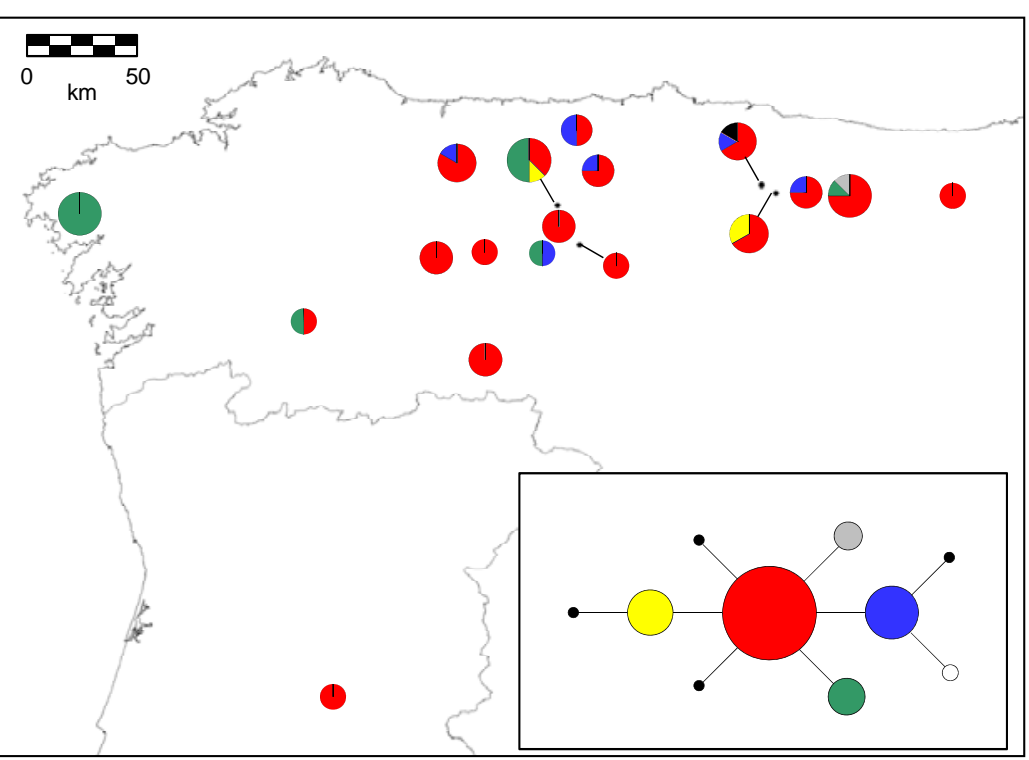

Page | 28 
(c)
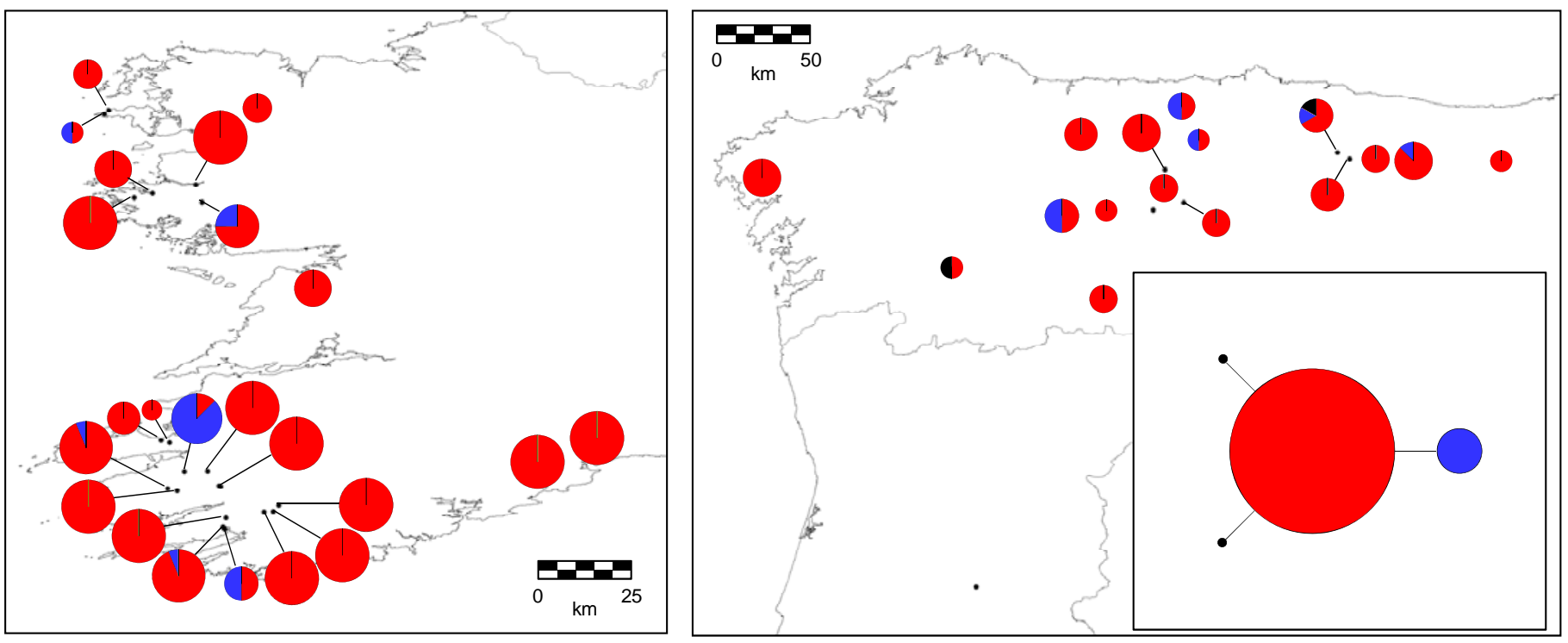

(d)
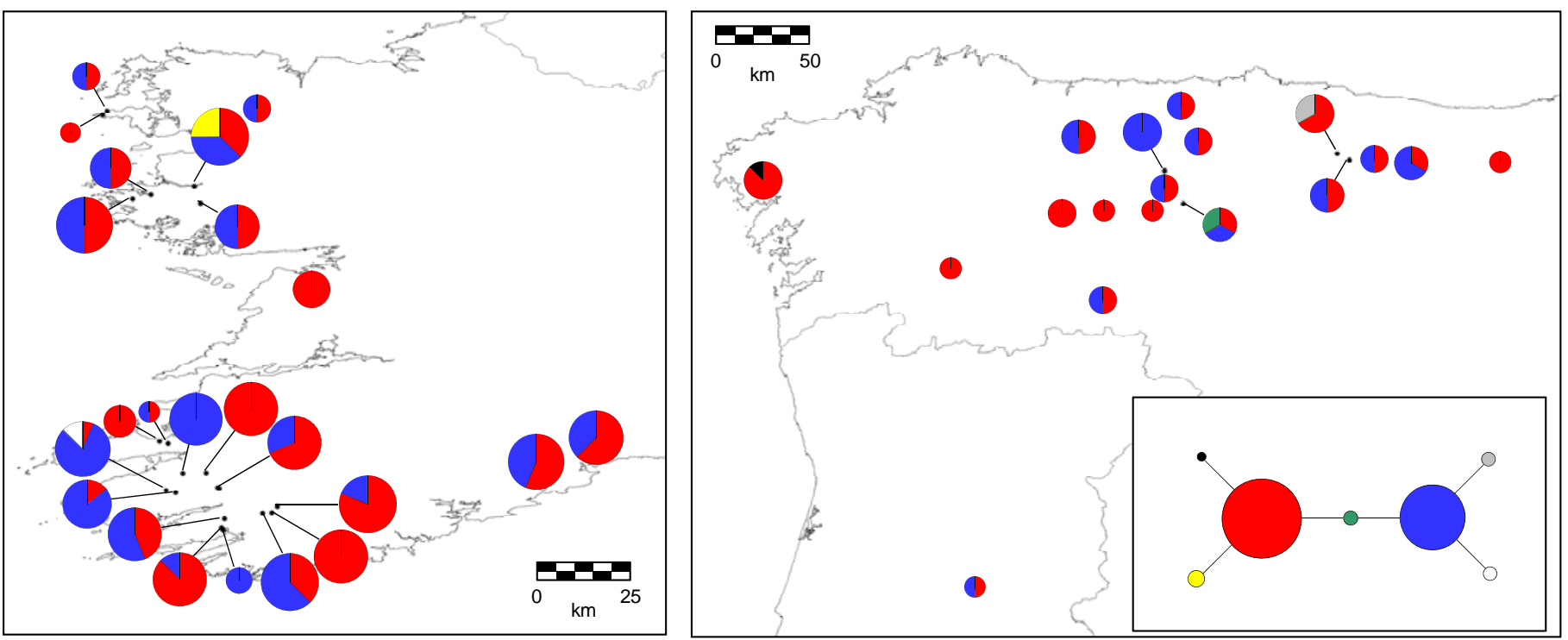

Page | 29 
Appendix S1a Samples of Pinguicula grandiflora analysed

\begin{tabular}{|c|c|c|c|c|c|c|c|c|}
\hline \multirow[t]{2}{*}{ Country } & \multirow[t]{2}{*}{ Location } & \multirow[t]{2}{*}{ Code* } & \multirow[t]{2}{*}{ Lat $(\mathrm{N})$} & \multirow[t]{2}{*}{ Long (W) } & \multicolumn{4}{|c|}{$n$} \\
\hline & & & & & $\operatorname{trnL}-\mathrm{F}$ & Pg-C01 & Pg-F02 & Pg-F10 \\
\hline \multirow[t]{3}{*}{ France } & Pyrénées-Atlantiques & G-00308102 & 43.2503 & 0.8794 & 1 & 1 & 1 & 1 \\
\hline & Bagnère-de-Luchon & G-00308101 & 43.1183 & -1.2436 & 1 & 1 & 1 & 1 \\
\hline & Près Lajoux & G.00308100 & 46.7392 & -5.7289 & 1 & 1 & 1 & 1 \\
\hline \multirow{10}{*}{ Ireland } & Lough Cloon 1 & & 51.9573 & 9.8530 & 6 & 6 & 4 & 5 \\
\hline & Lough Cloon 2 & & 51.9547 & 9.8525 & 8 & 8 & 8 & 8 \\
\hline & Gap of Dunloe & & 51.9892 & 9.6562 & 8 & 8 & 2 & 8 \\
\hline & Galway Bridge & & 51.9628 & 9.5793 & 7 & 8 & 8 & 8 \\
\hline & Gougane Barra & & 51.8333 & 9.3450 & 7 & 8 & 7 & 8 \\
\hline & Killarney National Park & & 52.0155 & 9.2461 & 8 & 8 & 6 & 7 \\
\hline & Priest's Leap & & 51.7781 & 9.4564 & 6 & 6 & 6 & 6 \\
\hline & Healy Pass & & 51.7152 & 9.7270 & 6 & 6 & 6 & 6 \\
\hline & Slieve Mish & & 52.1881 & 9.8773 & 6 & 6 & 6 & 6 \\
\hline & Burren & & 53.1258 & 9.2699 & 6 & 6 & 6 & 6 \\
\hline \multirow{13}{*}{ Spain } & Valdés & FCO-15016 & 43.46 & 6.56 & 6 & 6 & 6 & 6 \\
\hline & Villariño del Sil & LEB-15742 & 42.8737 & 6.4289 & 4 & 4 & 4 & 4 \\
\hline & Puerto de Leitariegos & LEB-13532 & 42.9637 & 6.4252 & 4 & 4 & 4 & 4 \\
\hline & Yernes y Tameza & FCO-23468 & 43.24 & 6.12 & 3 & 2 & 1 & 2 \\
\hline & Puerto de la Ventana & SEV-68044 & 43.0568 & 6.0106 & - & 2 & 2 & 2 \\
\hline & Mirantes de Luna & LEB-3760 & 42.9099 & 5.88 & 5 & 5 & 5 & 4 \\
\hline & Branillín & LEB-63747 & 43.0044 & 5.7606 & 6 & 6 & 6 & 6 \\
\hline & Puerto de San Isidro & LEB-62112 & 43.0541 & 5.3502 & 5 & 5 & 5 & 5 \\
\hline & Cangas de Onís & FCO-26683 & 43.24 & 5.34 & 2 & 2 & 2 & 2 \\
\hline & Covadonga & SEV-25704 & 43.3088 & 5.0544 & 4 & 4 & 4 & 4 \\
\hline & Cabrales & FCO-13569 & 43.19 & 4.80 & 8 & 7 & 8 & 6 \\
\hline & Valdelateja & SEV-18909 & 42.7743 & 3.7687 & 7 & 6 & 8 & 7 \\
\hline & Merindad de Montija & SALA-103945/104063 & 43.13 & 3.43 & 3 & 3 & 3 & 2 \\
\hline
\end{tabular}


Appendix S1a (continued)

\begin{tabular}{|c|c|c|c|c|c|c|c|c|}
\hline \multirow{2}{*}{ Country } & \multirow[t]{2}{*}{ Location } & \multirow[t]{2}{*}{ Code* } & \multirow[t]{2}{*}{ Lat $(\mathrm{N})$} & \multirow[t]{2}{*}{ Long (W) } & \multicolumn{4}{|c|}{$n$} \\
\hline & & & & & $\operatorname{trnL}-\mathrm{F}$ & Pg-C01 & Pg-F02 & Pg-F10 \\
\hline \multirow{13}{*}{ Spain } & Valgañón & SALA-100469 & 42.32 & 3.10 & 3 & 3 & 3 & 2 \\
\hline & Ezcaray & SALA-100470 & 42.25 & 2.98 & 2 & 2 & 2 & 2 \\
\hline & Riopar & SEV-53522 & 38.499 & 2.417 & 2 & 1 & - & 1 \\
\hline & Aia & SALA-88654 & 43.23 & 2.17 & 2 & 2 & 2 & 2 \\
\hline & Valle del Roncal & SEV-91312 & 42.9265 & 1.6515 & 4 & 4 & 3 & 3 \\
\hline & Roncesvalles & SEV-224332 & 43.0135 & 1.3157 & 2 & 2 & 2 & - \\
\hline & Sallent de Gállego & FCO-7678/SEV-69895 & 42.79 & 0.33 & 7 & 6 & 4 & 5 \\
\hline & Beceite & BC-905331 & 40.8311 & -0.1796 & 2 & 1 & 2 & 2 \\
\hline & Roquetes & BC-905330 & 40.8207 & -0.5018 & 2 & 1 & 2 & 1 \\
\hline & Valle de Arán & SALA-10903 & 42.61 & -0.68 & 3 & 3 & 3 & 2 \\
\hline & Arcalis & BC-912895 & 42.3542 & -1.0838 & 3 & 2 & 3 & 3 \\
\hline & Queralbs & SEV-92951 & 42.3505 & -2.1710 & - & 4 & 3 & 3 \\
\hline & & & & & 160 & 160 & 149 & 151 \\
\hline
\end{tabular}

* Herbarium codes: G - Université de Genève; FCO - Universidad de Oviedo Herbario; LEB - Universidad de León Herbario; SEV Universidad de Sevilla Herbario; SALA - Universidad de Salamanca Herbario; BC - Herbari BC, Institut Botànic de Barcelona. 
Appendix S1b Samples of Saxifraga spathularis analysed

\begin{tabular}{|c|c|c|c|c|c|c|c|c|}
\hline \multirow{2}{*}{ Country } & \multirow[t]{2}{*}{ Location } & \multirow[t]{2}{*}{ Code* } & \multirow[t]{2}{*}{ Lat $(\mathrm{N})$} & \multirow[t]{2}{*}{ Long (W) } & \multicolumn{4}{|c|}{$n$} \\
\hline & & & & & $\operatorname{trnS}-\mathrm{G}$ & Ss-C02 & Ss-G04 & Ss-G07 \\
\hline \multirow[t]{23}{*}{ Ireland } & Croaghaun Mountain & DBN-6031 & 53.9789 & 10.2047 & 1 & 1 & 1 & 1 \\
\hline & Lough Bunafreva & DBN-6033 & 54.0000 & 10.1803 & 2 & 1 & 2 & 2 \\
\hline & Streamstown & DBN-6010/6017/6018/6021 & 53.5267 & 10.0438 & 8 & 7 & 8 & 8 \\
\hline & Connemara National Park & & 53.5509 & 9.9454 & 4 & 4 & 4 & 4 \\
\hline & Dingle Peninsula & & 52.2168 & 9.9000 & 3 & 3 & 3 & 3 \\
\hline & Lough Cloon & & 51.9547 & 9.8653 & 8 & 6 & 8 & 8 \\
\hline & Caherconree & DBN-6020 & 52.2030 & 9.8537 & 1 & - & 1 & 1 \\
\hline & Ballaghbeama Gap & & 51.9432 & 9.8128 & 7 & 7 & 7 & 7 \\
\hline & Glancuttaun & & 52.045 & 9.775 & 8 & 2 & 8 & 8 \\
\hline & Leenaun & & 53.5972 & 9.7134 & 8 & 8 & 8 & 8 \\
\hline & Mamean & & 53.505 & 9.679 & 3 & 6 & 6 & 6 \\
\hline & Gap of Dunloe & & 52.0466 & 9.6500 & 8 & 7 & 8 & 8 \\
\hline & Galway Bridge & & 51.9665 & 9.5794 & 8 & 8 & 8 & 8 \\
\hline & Glengariff & & 51.7500 & 9.5667 & 8 & 6 & 8 & 8 \\
\hline & Lady Bantries Lookout & & 51.7415 & 9.5565 & 3 & 3 & 3 & 2 \\
\hline & Druidsview & & 51.80 & 9.55 & 8 & 8 & 8 & 8 \\
\hline & Nephin Mountain & DBN-6026 & 54.0138 & 9.3684 & 2 & 2 & 2 & 2 \\
\hline & Gougane Barra 1 & & 51.8333 & 9.3450 & 8 & 8 & 8 & 8 \\
\hline & Gougane Barra 2 & & 51.8340 & 9.2954 & 8 & 7 & 8 & 8 \\
\hline & Coomdorragh & & 51.8691 & 9.2658 & 8 & 8 & 8 & 8 \\
\hline & Burren & & 53.0352 & 9.0769 & 4 & 4 & 4 & 4 \\
\hline & Curragraig & & 52.1049 & 7.8657 & 8 & 8 & 8 & 8 \\
\hline & Mahon Falls & & 52.2324 & 7.5470 & 8 & 8 & 8 & 8 \\
\hline
\end{tabular}


Appendix S1b (continued)

\begin{tabular}{|c|c|c|c|c|c|c|c|c|}
\hline \multirow[t]{2}{*}{ Country } & \multirow[t]{2}{*}{ Location } & \multirow[t]{2}{*}{ Code* } & \multirow[t]{2}{*}{ Lat $(\mathrm{N})$} & \multirow[t]{2}{*}{ Long (W) } & \multicolumn{4}{|c|}{$n$} \\
\hline & & & & & $\operatorname{trnS}-\mathrm{G}$ & Ss-C02 & Ss-G04 & Ss-G07 \\
\hline Portugal & Sierra de la Estrella & MGC-13014 & 40.3281 & 7.6327 & 1 & 1 & - & 1 \\
\hline \multirow[t]{18}{*}{ Spain } & Mazaricos & SANT-110427 & 42.9389 & 8.9922 & 4 & 4 & 4 & 4 \\
\hline & Los Peares & SALA-99560 & 42.36 & 7.79 & 1 & 1 & 1 & 1 \\
\hline & Cebreiro & SALA-115510 & 42.70 & 7.08 & 2 & 2 & 3 & 2 \\
\hline & La Coba & SALA-59413 & 43.21 & 6.97 & 3 & 3 & 3 & 3 \\
\hline & Peña Trevinca & FCO-15020 & 42,16 & 6.82 & 2 & 2 & 2 & 2 \\
\hline & Villar de Acero & LEB-48167 & 42.7286 & 6.8135 & 1 & 1 & 1 & 1 \\
\hline & Toreno & LEB-78833 & 42.7322 & 6.5044 & 1 & 1 & - & 1 \\
\hline & Cueto de Arbás & LEB-92470 & 42.9923 & 6.4299 & 4 & 4 & 4 & 4 \\
\hline & Villariño del Sil & LEB-17789 & 42.8737 & 6.4289 & 2 & 2 & 2 & 2 \\
\hline & Salas & FCO-29610 & 43.40 & 6.32 & 2 & 2 & 2 & 2 \\
\hline & Murias de Paredes & LEB-44527 & 42.7810 & 6.3105 & 1 & 1 & 2 & 3 \\
\hline & Pico la Berza & FCO-24445 & 43.18 & 6.21 & 2 & 2 & 1 & 2 \\
\hline & Caso & FCO-22519 & 43.10 & 5.33 & 3 & 3 & 3 & 3 \\
\hline & Pinar de Lillo & MGC-12919 & 43.0594 & 5.2832 & 3 & 3 & 3 & 3 \\
\hline & Puerto del Pontón & LEB-86557 & 43.0637 & 5.0878 & 2 & 2 & 2 & 2 \\
\hline & Portilla de la Reina & SALA-114146 & 43.04 & 4.85 & 4 & 4 & 4 & 3 \\
\hline & Polaciones & MGC-61618 & 43.04 & 4.29 & 1 & 1 & 1 & 1 \\
\hline & & & & & 173 & 161 & 175 & 176 \\
\hline
\end{tabular}

* Herbarium codes: DBN - National Botanic Gardens of Ireland, Glasnevin; MGC - Universidad de Málaga Herbario, SANT - Universidad de Santiago de Compostela Herbario; SALA - Universidad de Salamanca Herbario; FCO - Universidad de Oviedo Herbario; LEB - Universidad de León Herbario 
Appendix S2 PCR / sequencing primers used in this study.

\begin{tabular}{|c|c|c|c|c|}
\hline Species & Primer & Sequence (5' - 3’) & Size (bp) ${ }^{b}$ & Source \\
\hline \multirow[t]{10}{*}{ P. grandiflora } & trnLF-F & GCTGTTCTAACAAATGGGGTTG & 712 & GenBank AF482623 \\
\hline & $\operatorname{trnLF}-\mathrm{R}$ & CTGAGCTATCCCGACCATTC & & \\
\hline & $\operatorname{trnLF}-I N-R^{\mathrm{a}}$ & GAGAAACATTTTGGGAGTCAAATAG & & \\
\hline & $\operatorname{trnLF}-\mathrm{IN}-\mathrm{F}^{\mathrm{a}}$ & CTATTTGACTCCCAAAATGTTTCTC & & \\
\hline & Pg-C01-F & AGCAAGAGAAGGAAAATAAGAGTTT & 206 & This study \\
\hline & Pg-C01-R & GCTCATAGACTACTGATACTTGAGCA & & \\
\hline & Pg-F02-F & TCTTGCATGGGTAGTTGGTG & 400 & This study \\
\hline & Pg-F02-R & GTTGGCGTATGAAATTGTTGC & & \\
\hline & Pg-F10-F & ATAGGCCCGTGGCTGAAGT & 292 & This study \\
\hline & Pg-F10-R & ACAATGGAATCCCCGACAG & & \\
\hline \multirow[t]{12}{*}{ S. spathularis } & $\operatorname{trnSG}-\mathrm{F}$ & GCCGCTTTAGTCCACTCAGC & 882-914 & Hamilton (1999) \\
\hline & $\operatorname{trnSG-R}$ & GAACGAATCACACTTTTACCAC & & Mol. Ecol. 8, 521-523 \\
\hline & $\operatorname{trnSG}-\mathrm{IN}-\mathrm{R} 1^{\mathrm{a}}$ & GATAAACGTGATATATTTGTATC & & \\
\hline & $\operatorname{trnSG}-\mathrm{IN}-\mathrm{F} 1^{\mathrm{a}}$ & GATACAAATATATCACGTTTATC & & \\
\hline & $\operatorname{trnSG}-I N-R 2^{\mathrm{a}}$ & ATACTTGAATTCCCTATCATAG & & \\
\hline & $\operatorname{trnSG}-I N-F 2^{\mathrm{a}}$ & CTATGATAGGGAATTCAAGTAT & & \\
\hline & Ss-C02-F & САССССАТТАССТСАТТСТТАGG & $400(84)$ & This study \\
\hline & Ss-C02-R & TCGGCCACTATAAAGTTTTTCC & & \\
\hline & Ss-G04-F & TCССТСТСТGAATAACACACGA & $372(95)$ & This study \\
\hline & Ss-G04-R & TGGGAACGTAACCACAAACA & & \\
\hline & Ss-G07-F & CACGCCCCTAAAATAGAAGAAA & $400(211)$ & This study \\
\hline & Ss-G07-R & ACGACTAAATCAACAATGGAGTC & & \\
\hline
\end{tabular}

\footnotetext{
${ }^{\mathrm{a}}$ Internal primer

${ }^{\mathrm{b}}$ Figure in parenthesis indicates largest non-recombining portion used for analysis
} 

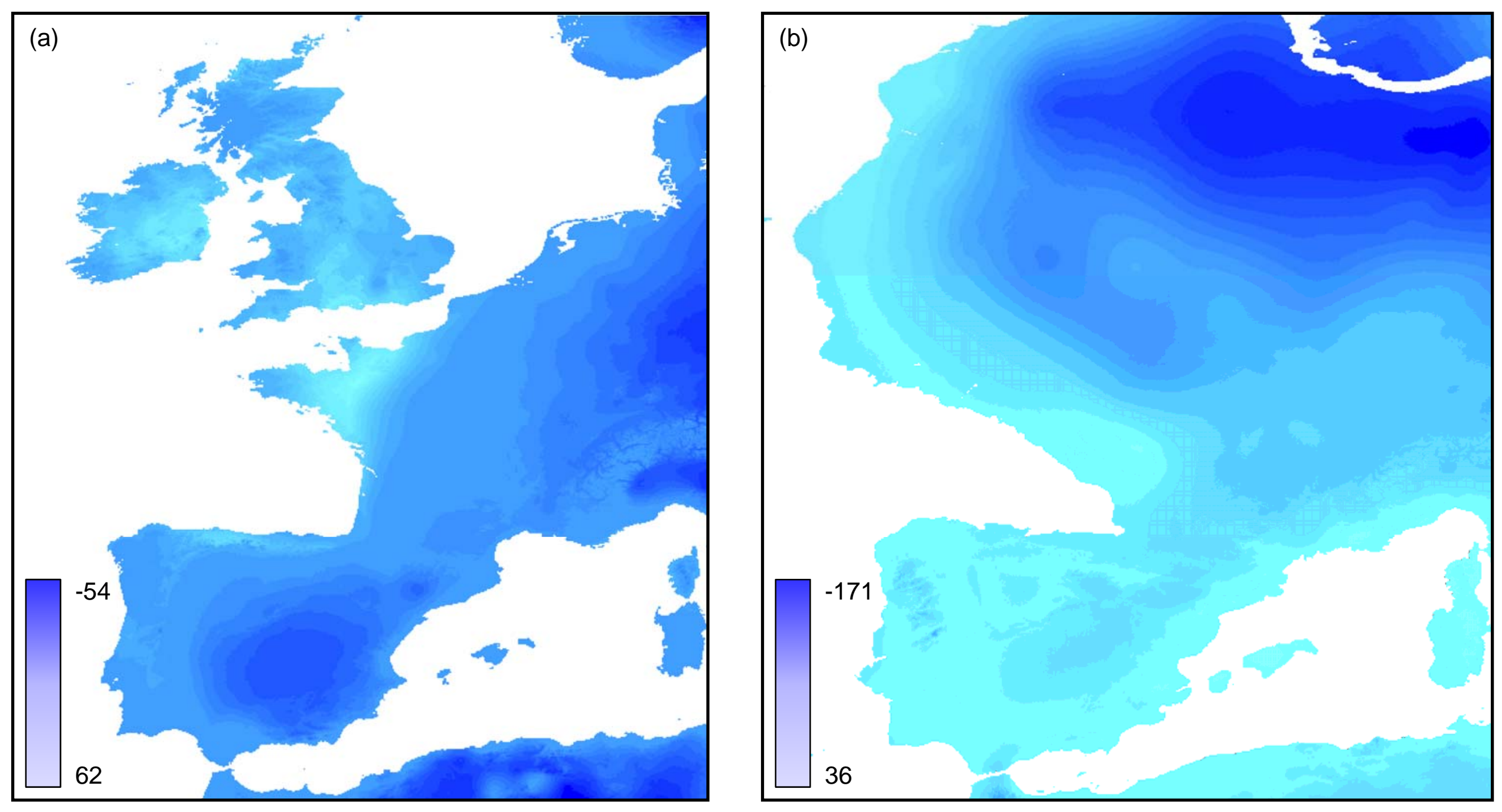